Sains Malaysiana 50(12)(2021): 3569-3582

http://doi.org/10.17576/jsm-2021-5012-09

\title{
Cyanamide-Modified Iron (III) Oxide Photocatalysts for Degradation of Phenol in the Presence of Urea and Formaldehyde
}

(Ferum(III) Oksida Terubahsuai Sianamida sebagai Fotomangkin untuk Penguraian Fenol dengan Kehadiran Urea dan Formaldehid)

\author{
NUR AZMinA RosLAN*, HENDRIK O. LINTANG \& LENY YULIATI*
}

\begin{abstract}
Cyanamide as the source of carbon and nitrogen was used to modify iron(III) oxide ( $\left.\mathrm{Fe}_{2} \mathrm{O}_{3}\right)$ photocatalyst. While X-ray diffraction (XRD) patterns confirmed that the cyanamide-modified $\mathrm{Fe}_{2} \mathrm{O}_{3}$ photocatalysts have comparable crystallinity to that of the unmodified $\mathrm{Fe}_{2} \mathrm{O}_{3}$, the diffuse reflectance ultraviolet-visible (DR UV-vis) spectra obviously showed additional light absorption around 500-800 $\mathrm{nm}$ on the cyanamide-modified $\mathrm{Fe}_{2} \mathrm{O}_{3}$, resulting in a better absorption capability under visible light irradiation. The presence of cyanamide modifier decreased the fluorescence emission intensity of $\mathrm{Fe}_{2} \mathrm{O}_{3}$, implying the reduced electron-hole recombination on the $\mathrm{Fe}_{2} \mathrm{O}_{3}$ and/or blocked emission sites by the modifier. The presence of carbon and nitrogen on the modified $\mathrm{Fe}_{2} \mathrm{O}_{3}$ photocatalysts was confirmed by the elemental analyzer. Photocatalytic activities of $\mathrm{Fe}_{2} \mathrm{O}_{3}$ and cyanamide-modified $\mathrm{Fe}_{2} \mathrm{O}_{3}$ were then evaluated for degradation of phenol under UV and visible light irradiation. Modification of $\mathrm{Fe}_{2} \mathrm{O}_{3}$ with cyanamide significantly improved the degradation of phenol from 30 to $75 \%$ under UV light irradiation and from 0 to $80 \%$ under visible light irradiation. Photocatalytic degradation of phenol was also investigated in the presence of urea or formaldehyde or both urea and formaldehyde. Even though the percentage of phenol degradation decreased in the presence of other pollutants, it was demonstrated that cyanamide modified iron(III) oxide photocatalysts still gave good activity towards degradation of phenol even in the presence of other organic pollutants.
\end{abstract}

Keywords: Cyanamide; formaldehyde; iron (III) oxide; phenol; photocatalyst; urea

ABSTRAK

Sianamida sebagai sumber karbon dan nitrogen telah digunakan untuk mengubah suai fotomangkin ferum(III) oksida $\left(\mathrm{Fe}_{2} \mathrm{O}_{3}\right)$. Corak teknik pembelauan sinar-X (XRD) mengesahkan bahawa fotomangkin $\mathrm{Fe}_{2} \mathrm{O}_{3}$ terubah suai sianamida mempunyai kristaliniti yang setanding dengan $\mathrm{Fe}_{2} \mathrm{O}_{3}$ yang tidak diubah dan spektrum DR UV-vis jelas menunjukkan penyerapan cahaya tambahan sekitar 500-800 $\mathrm{nm}$ pada $\mathrm{Fe}_{2} \mathrm{O}_{3}$ terubah suai sianamida, lalu menghasilkan keupayaan penyerapan yang lebih baik di bawah cahaya tampak. Kehadiran pengubah sianamida menurunkan keamatan pendarcahaya $\mathrm{Fe}_{2} \mathrm{O}_{3}$, mengurangkan penggabungan semula elektron-lubang dan/atau menyekat tapak pemancaran pada $\mathrm{Fe}_{2} \mathrm{O}_{3}$. Kehadiran karbon dan nitrogen pada fotomangkin $\mathrm{Fe}_{2} \mathrm{O}_{3}$ yang telah diubah suai telah disahkan oleh analisis unsur. Aktiviti fotopemangkinan $\mathrm{Fe}_{2} \mathrm{O}_{3}$ dan $\mathrm{Fe}_{2} \mathrm{O}_{3}$ yang diubah suai sianamida kemudiannya dinilai untuk penguraian fenol di bawah sinaran UV dan cahaya tampak. Pengubahsuaian $\mathrm{Fe}_{2} \mathrm{O}_{3}$ dengan sianamida meningkatkan penguraian fenol dari 30 hingga 75\% di bawah sinaran UV dan dari 0 hingga $80 \%$ di bawah cahaya tampak. Penguraian fotopemangkinan fenol juga dikaji dengan adanya urea atau formaldehid atau kedua-duanya. Walaupun peratusan penguraian fenol menurun dengan kehadiran bahan pencemar lain, fotomangkin $\mathrm{Fe}_{2} \mathrm{O}_{3}$ terubah suai sianamida masih memberikan aktiviti yang baik terhadap penguraian fenol walaupun dengan kehadiran bahan pencemar organik lain.

Kata kunci: Fenol; ferum (III) oksida; fotomangkin; sianamid; urea

\section{INTRODUCTION}

Iron (III) oxide $\left(\mathrm{Fe}_{2} \mathrm{O}_{3}\right)$ or hematite is known as a remarkable stable iron oxide. Owing to its narrow bandgap energy (ca. $2.2 \mathrm{eV}), \mathrm{Fe}_{2} \mathrm{O}_{3}$ not only shows strong absorption in the ultraviolet region but also in the visible light region, giving a blood-red color appearance (Cornell \& Schwertmann 2003). While it has been recognized as one 
important pigment in industries, this property is especially useful for photocatalysis applications, especially for solar light utilization considering that solar spectrum consists of $c a$. $40 \%$ of visible light. Since it is also stable and relatively cheap, $\mathrm{Fe}_{2} \mathrm{O}_{3}$ has been widely explored for various photocatalytic applications such as water splitting reactions (Lin et al. 2011; Qiu et al. 2014; Sivula et al. 2011), degradation and decomposition of dyes (Liu et al. 2012; Sundaramurthy et al. 2012; Xu et al. 2013; Yang et al. 2012) and other organic pollutants (Cao \& Zhu 2011; Li et al. 2009; Roslan et al. 2014), as well as for some selective oxidation and polymerization reactions (Karunakaran \& Senthilvelan 2006; Stroyuk et al. 2007). The addition of $\mathrm{Fe}_{2} \mathrm{O}_{3}$ onto another semiconductor photocatalyst such as $\mathrm{TiO}_{2}$ has been also reported to give a significant contribution to improve the activity of the $\mathrm{TiO}_{2}$ semiconductor (Cheng et al. 2017; Lee et al. 2017; Mou et al. 2012). Unfortunately, the photocatalytic activity of $\mathrm{Fe}_{2} \mathrm{O}_{3}$ is still considered low as it exhibits a high charge recombination.

Several modifications have been reported to further improve the photocatalytic activity of $\mathrm{Fe}_{2} \mathrm{O}_{3}$, such as via the addition of noble metal co-catalysts (Cao et al. 2012; Chen et al. 2012), making composites with carbon materials (Guo et al. 2013; Li et al. 2013; Mohamed et al. 2020; Yu \& Kwak 2012; Zhang et al. 2011) and other oxides (Bassi et al. 2016; Hou et al. 2013), and also the addition of metal (Chemelewski et al. 2016; Mirbagheri et al. 2014; Zhang et al. 2010) and non-metal dopants (Pradhan et al. 2013; Wen \& Pan 2012; Zhang et al. 2015). Modification with non-metal co-dopants is particularly interesting, such as in the $\mathrm{S}$ and $\mathrm{N}$ co-doped $\mathrm{Fe}_{2} \mathrm{O}_{3}$ originated from thiourea as the source (Pradhan et al. 2013). The $\mathrm{S}$ and $\mathrm{N}$ co-dopants were found to reduce the electron-holes recombination on the $\mathrm{Fe}_{2} \mathrm{O}_{3}$, which resulted in the improvement of photocatalytic activity for the degradation of Rhodamine B under natural sunlight irradiation. On the other hand, the DFT calculations showed that $\mathrm{F}$ and $\mathrm{N}$ co-dopants would improve the activity of $\mathrm{Fe}_{2} \mathrm{O}_{3}$, where the $\mathrm{F}$ dopant would reduce the charge carrier recombination, while the $\mathrm{N}$ dopant would help to reduce the band gap energy to increase the utilization ratio of solar energy (Wen \& Pan 2012). Other important co-dopants are carbon and nitrogen, which have been used widely for activity improvements in various semiconductors such as titanium dioxide (Abdullah et al. 2016; Dolat et al. 2012; Mohamed et al. 2019, 2017) and zinc oxide (Liang et al. 2016) but have not yet been utilized for activity improvement in $\mathrm{Fe}_{2} \mathrm{O}_{3}$.

In this study, cyanamide was used as the source of carbon and nitrogen to modify $\mathrm{Fe}_{2} \mathrm{O}_{3}$. Cyanamide has been used as a good carbon and nitrogen source in the preparation of metal nitrides (Buha et al. 2007), metal carbides ( $\mathrm{Li}$ et al. 2008), and metal cyanamide (Zhao et al. 2013). It has been also used as a precursor to synthesize carbon nitride (Thomas et al. 2008; Wang et al. 2012). The photocatalytic performance of the $\mathrm{Fe}_{2} \mathrm{O}_{3}$ and modified $\mathrm{Fe}_{2} \mathrm{O}_{3}$ was then evaluated for degradation of phenol in the absence and presence of other pollutants, which were urea, formaldehyde, or a mixture of urea and formaldehyde under UV and visible light irradiation. Phenol constitutes one of the toxic compounds from industrial wastes such as from pulp and paper industry, mining and coal combustion, and palm oil industry (Yusoff et al. 2017). Besides phenol, other organic pollutants also exist in the wastes and thus, efforts to degrade phenol in the presence of other pollutants would be also an important approach. For instance, urea and formaldehyde are generally also found in the phenolic resin effluent. This study demonstrated that the modified $\mathrm{Fe}_{2} \mathrm{O}_{3}$ photocatalyst could degrade phenol under UV or visible light and the phenol degradation can still be realized even though in the presence of urea, formaldehyde, and mixture of urea and formaldehyde.

\section{EXPERIMENTAL DETAILS PREPARATION OF PHOTOCATALYST}

All chemicals were used as received without further purification. Iron(II) chloride tetrahydrate $\left(\mathrm{FeCl}_{2} \cdot 4 \mathrm{H}_{2} \mathrm{O}\right.$, $99 \%$, QRëc) was used as the iron source, while cyanamide $\left(\mathrm{CH}_{2} \mathrm{~N}_{2}, 99 \%\right.$, Aldrich) was used as the carbon and nitrogen source. The iron salt was dissolved first in the methanol and the cyanamide was added in the mixture with different mol ratios of cyanamide to $\mathrm{FeCl}_{2} \cdot 4 \mathrm{H}_{2} \mathrm{O}$. The mixture was stirred vigorously for $2 \mathrm{~h}$ at around $343-353 \mathrm{~K}$ in a paraffin oil bath. The resulting dark brown mixture was taken out and transferred into a ceramic crucible, followed by heat treatment at $823 \mathrm{~K}$ for $4 \mathrm{~h}$. After the heating process, the modified $\mathrm{Fe}_{2} \mathrm{O}_{3}$ photocatalysts were collected and denoted as $\mathrm{Fe}_{2} \mathrm{O}_{3}-$ $\mathrm{CN}(x)$ where $x$ indicates the initial mol ratio of cyanamide to iron precursor $(x=2-10)$. As a comparison, the $\mathrm{Fe}_{2} \mathrm{O}_{3}$ was prepared in a similar way except that the synthesis was carried out without the addition of cyanamide and the iron salt was directly heated to reach $823 \mathrm{~K}$ and the temperature was maintained for $4 \mathrm{~h}$.

\section{CHARACTERIZATIONS OF PHOTOCATALYST}

$\mathrm{X}$-ray diffraction (XRD) patterns of the prepared samples were recorded using a Bruker AXS Diffrac plus release 2000 at room temperature and using $\mathrm{Cu}-\mathrm{K} \alpha$ radiation $(\lambda=1.5406 \AA)$ at $40 \mathrm{kV}$ and $40 \mathrm{~mA}$. The absorption spectra were measured by using a Perkin Elmer 
Lambda 900 diffuse reflectance UV-visible (DR UVvis) spectroscopy. The barium sulfate was used as the reference. Fluorescence spectra were measured on a JASCO Spectrofluorometer FP-8500. The monitoring wavelengths for excitation and emission spectra were 217 and $276 \mathrm{~nm}$, respectively. Scanning electron microscopy (SEM) images of the prepared samples were taken using a JEOL JSM-6390LV with an accelerating voltage of $15 \mathrm{kV}$. Before analysis, the samples were coated with platinum (Pt) by using JEOL auto fine coater for $52 \mathrm{~s}$ under vacuum condition, followed by the second coating for another $40 \mathrm{~s}$. In order to determine the content of carbon, hydrogen, and nitrogen, Thermo Scientific FLASH 2000 was used as an elemental analyzer. The sample was combusted under an oxygen atmosphere at a temperature of $1333 \mathrm{~K}$ for $12 \mathrm{~min}$.

\section{PHOTOCATALYTIC TESTS}

The photocatalytic activities of the prepared samples were evaluated for degradation of phenol $\left(\mathrm{C}_{6} \mathrm{H}_{5} \mathrm{OH}\right.$, Scharlau, $99.5 \%$ ) in the absence and presence of urea $\left(\mathrm{CO}\left(\mathrm{NH}_{2}\right)_{2}\right.$, Merck, 99.5\%) or formaldehyde (HCHO, Merck, 37\%) or a mixture of urea and formaldehyde under both UV and visible light irradiation. UV lamp used was a UVP UVLS-28 EL series that emits UV light centered at $254 \mathrm{~nm}\left(8 \mathrm{~W}\right.$, intensity $\left.=0.8 \mathrm{~mW} / \mathrm{cm}^{2}\right)$. The visible lamp that was used was a halogen fiber optic illuminator Dolan-Jenner Fiber-Lite MI-157 (150 W, intensity $=70000 \mathrm{~lx}$ ). As for the photocatalytic removal of phenol, the prepared photocatalyst $(0.25 \mathrm{~g})$ was dispersed in phenol solution (50 ppm, $50 \mathrm{~mL}$ ) in an open reactor system attached with a water cooling system in order to maintain the reaction temperature to be close to room temperature. Prior to the reaction, the phenol solution was stirred for $2 \mathrm{~h}$ in dark condition in order to reach the equilibrium. The solution was subsequently exposed to UV or visible light irradiation for $25 \mathrm{~h}$. After the reaction, the photocatalyst was removed by filtration from the solution. The filtrate was analyzed by GC-FID using a BPX5 column. The photocatalytic reactions were also conducted in the presence of urea, formaldehyde, or both urea and formaldehyde. The concentration of urea or formaldehyde was fixed to be the same to phenol concentration or in excess, which gave phenol-urea (1:1 and 1:300), phenol-formaldehyde (1:1 and 1:300), and phenol-urea-formaldehyde solutions $(1: 1: 1$ and 1:300:300). The percentage of phenol degradation was calculated based on the ratio of concentrations between the reacted and the initial phenol.

\section{RESULTS AND DISCUSSION}

PROPERTIES OF THE $\mathrm{FE}_{2} \mathrm{O}_{3}$-CN $(X)$ SAMPLES

Figure 1(a) shows the XRD patterns of the prepared $\mathrm{Fe}_{2} \mathrm{O}_{3}$ as well as the cyanamide-modified $\mathrm{Fe}_{2} \mathrm{O}_{3}$ samples with various initial mol ratios of cyanamide to the iron precursor $(x=2-10)$. All the prepared $\mathrm{Fe}_{2} \mathrm{O}_{3}$ and cyanamide-modified $\mathrm{Fe}_{2} \mathrm{O}_{3}$ samples exhibited the characteristic diffraction peaks of $\mathrm{Fe}_{2} \mathrm{O}_{3}(\mathrm{CaO} \& \mathrm{Zhu}$ 2011; Chen et al. 2012; Cornell \& Schwertmann 2003; Li et al. 2013, 2009; Liu et al. 2012; Mirbagheri et al. 2014; Pradhan et al. 2013; Roslan et al. 2014; Sundaramurthy et al. 2012; Thomas at al. 2015; Xu et al. 2013; Yang et al. 2012; Yu \& Kwak 2012; Zhang et al. 2011). Other peaks were not detected, suggesting that the presence of cyanamide even in high amount did not induce the formation of new species and did not much disturb the structure of $\mathrm{Fe}_{2} \mathrm{O}_{3}$. However, peak intensities of these $\mathrm{Fe}_{2} \mathrm{O}_{3}-\mathrm{CN}(x)$ samples were found to be much lower than those of the bulk $\mathrm{Fe}_{2} \mathrm{O}_{3}$. The effect of cyanamide on the decrease of the peak intensity was more pronounced on samples with a higher ratio, such as in $\mathrm{Fe}_{2} \mathrm{O}_{3}-\mathrm{CN}(8)$ and $\mathrm{Fe}_{2} \mathrm{O}_{3}-\mathrm{CN}(10)$ as shown in Figure 1(e) and 1(f), respectively. This result showed that the presence of cyanamide modifier might inhibit the formation of $\mathrm{Fe}_{2} \mathrm{O}_{3}$ during the heating process, and this led to the reduced crystallinity of the prepared samples.

Figure 2 shows the DR UV-vis spectra of prepared $\mathrm{Fe}_{2} \mathrm{O}_{3}$ and $\mathrm{Fe}_{2} \mathrm{O}_{3}-\mathrm{CN}(x)$ samples. All samples exhibited absorption peaks at $c a .390 \mathrm{~nm}$, attributing to the $\mathrm{Fe}-\mathrm{O}$ bond $(\pi-3 d)$ due to the ligand-metal charge transfer (LMCT), while peaks around 500-800 nm would be due to the $d-d$ transitions of the Fe-Fe bond (Pradhan et al. 2013; Roslan et al. 2014). It was obvious that the addition of cyanamide increased the absorption level at $c a$. 600$800 \mathrm{~nm}$ with unclear band edge absorption, but did not affect the absorption peaks of original $\mathrm{Fe}_{2} \mathrm{O}_{3}$. Since all of the prepared $\mathrm{Fe}_{2} \mathrm{O}_{3}-\mathrm{CN}(x)$ samples could absorb UV and even showed better capability in absorbing visible light region compared to the $\mathrm{Fe}_{2} \mathrm{O}_{3}$, it can be expected that the prepared $\mathrm{Fe}_{2} \mathrm{O}_{3}-\mathrm{CN}(x)$ samples would have the ability to be active in both regions. In order to confirm the existence of carbon and hydrogen on the $\mathrm{Fe}_{2} \mathrm{O}_{3}-\mathrm{CN}(x)$ samples, a $\mathrm{CHN}$ analyzer was also used to measure the samples. As shown in Table $1, \mathrm{Fe}_{2} \mathrm{O}_{3}$ did not have carbon and nitrogen elements, while all the $\mathrm{Fe}_{2} \mathrm{O}_{3}-\mathrm{CN}(x)$ samples possess the low amount of carbon and nitrogen elements, which contents were much smaller than the theoretical added amount of cyanamide. For samples with high loading of cyanamide, the samples also consisted of the small amount of hydrogen element.

TABLE 1. Carbon, nitrogen, and hydrogen elemental analysis 
of $\mathrm{Fe}_{2} \mathrm{O}_{3}$ and $\mathrm{Fe}_{2} \mathrm{O}_{3}-\mathrm{CN}(x)$ samples

\begin{tabular}{lccc}
\hline \multicolumn{1}{c}{ Samples } & \multicolumn{3}{c}{ Composition of element (\%) } \\
& Carbon & Nitrogen & Hydrogen \\
\hline $\mathrm{Fe}_{2} \mathrm{O}_{3}$ & 0 & 0 & 0 \\
$\mathrm{Fe}_{2} \mathrm{O}_{3}-\mathrm{CN}(2)$ & 0.05 & 0.15 & 0 \\
$\mathrm{Fe}_{2} \mathrm{O}_{3}-\mathrm{CN}(4)$ & 0.09 & 0.16 & 0 \\
$\mathrm{Fe}_{2} \mathrm{O}_{3}-\mathrm{CN}(6)$ & 0.08 & 0.09 & 0 \\
$\mathrm{Fe}_{2} \mathrm{O}_{3}-\mathrm{CN}(8)$ & 6.71 & 11.37 & 1.15 \\
$\mathrm{Fe}_{2} \mathrm{O}_{3}-\mathrm{CN}(10)$ & 12.66 & 21.99 & 1.41 \\
\hline
\end{tabular}

Figure 3 shows the fluorescence emission spectra of $\mathrm{Fe}_{2} \mathrm{O}_{3}$ and $\mathrm{Fe}_{2} \mathrm{O}_{3}-\mathrm{CN}(x)$ samples when the spectra were measured at excitation wavelength of $217 \mathrm{~nm}$. There were five emission sites that could be observed, which were at $276,302,402,466$, and $545 \mathrm{~nm}$. It was confirmed that these five emission sites came from the same excitation site at $217 \mathrm{~nm}$, and the emission peak at $276 \mathrm{~nm}$ was the most intense peak among others. These multi-peaks suggested that these samples would have some defects as has been also observed on the $\mathrm{Fe}_{2} \mathrm{O}_{3}$ synthesized by a hydrothermal method (Thomas et al. 2015). The $\mathrm{Fe}_{2} \mathrm{O}_{3}$ showed higher emission intensity than the $\mathrm{Fe}_{2} \mathrm{O}_{3}-\mathrm{CN}(x)$ samples. High fluorescence emission intensity can be associated with the high electron-hole recombination, while the reduced intensity would show the decrease of the electron-hole recombination, which in many cases would lead to high photocatalytic activity. As can be seen in Figure 3, since all $\mathrm{Fe}_{2} \mathrm{O}_{3}-\mathrm{CN}(x)$ samples have a lower intensity than the $\mathrm{Fe}_{2} \mathrm{O}_{3}$, it can be suggested that the addition of cyanamide enhanced the separation of electron-hole pairs on the $\mathrm{Fe}_{2} \mathrm{O}_{3}-\mathrm{CN}(x)$ samples. The lower recombination of electron/hole pairs on $\mathrm{Fe}_{2} \mathrm{O}_{3}$ $\mathrm{CN}(x)$ samples would lead to the higher photocatalytic activity when compared to the bulk $\mathrm{Fe}_{2} \mathrm{O}_{3}$ without modification. While the $\mathrm{Fe}_{2} \mathrm{O}_{3}-\mathrm{CN}(2)$ showed a slightly lower intensity than that of the bulk $\mathrm{Fe}_{2} \mathrm{O}_{3}$, other $\mathrm{Fe}_{2} \mathrm{O}_{3}$ $\mathrm{CN}(x)$ samples showed reduced intensity with the increase of the cyanamide amount. The reduced intensity was more pronounced when the mol ratios of cyanamide were 8 and 10, suggesting that the reduced intensity observed on $\mathrm{Fe}_{2} \mathrm{O}_{3}-\mathrm{CN}(8)$ and $\mathrm{Fe}_{2} \mathrm{O}_{3}-\mathrm{CN}(10)$ shall be also considered from another reason, such as the emission sites on $\mathrm{Fe}_{2} \mathrm{O}_{3}$ were blocked by the compound containing carbon and nitrogen species as the result of excess added cyanamide.

Figure 4 shows the SEM image of the prepared $\mathrm{Fe}_{2} \mathrm{O}_{3}$ as well as the cyanamide-modified $\mathrm{Fe}_{2} \mathrm{O}_{3}$ samples. As shown in Figure 4(a), the prepared $\mathrm{Fe}_{2} \mathrm{O}_{3}$ has particles with non-uniform shape and size, which diameter was mainly in the wide range of 1-4 $\mu \mathrm{m}$. The large particles might be formed due to the sintering effect that occurred during the heating process. Shown in Figure 4(b) and 4(c) are the bulky structures of the $\mathrm{Fe}_{2} \mathrm{O}_{3}-\mathrm{CN}(2)$ and the $\mathrm{Fe}_{2} \mathrm{O}_{3}-\mathrm{CN}(4)$ samples, which were decorated with smaller particles, giving the large distribution of particle size in the range of 1-5 $\mathrm{mm}$. Since the particle size of these samples was large and has a similar size to that of the $\mathrm{Fe}_{2} \mathrm{O}_{3}$, it was proposed that the lower XRD peak intensity on the $\mathrm{Fe}_{2} \mathrm{O}_{3}-\mathrm{CN}(2)$ and the $\mathrm{Fe}_{2} \mathrm{O}_{3}-\mathrm{CN}(4)$ would not be due to the lower crystallite size, but the lower crystallinity. The $\mathrm{Fe}_{2} \mathrm{O}_{3}-\mathrm{CN}(6)$ sample showed the aggregation of the particles with non-uniform shapes and size (Figure 4(c)). Some small particles with a size of $0.5-1 \mathrm{~mm}$ can still be observed, but only as a small part of the sample. The aggregated particles were found to create large clusterlike particles with size up to $20 \mathrm{~mm}$. Samples with high loading amount of cyanamide, which were the $\mathrm{Fe}_{2} \mathrm{O}_{3}-$ $\mathrm{CN}(8)$ and the $\mathrm{Fe}_{2} \mathrm{O}_{3}-\mathrm{CN}(10)$, showed the slab structure as the dominant structure with small $\mathrm{Fe}_{2} \mathrm{O}_{3}$ particles were distributed on it.

\section{PHOTOCATALYTIC ACTIVITY OF THE $\mathrm{FE}_{2} \mathrm{O}_{3}$-CN $(X)$} SAMPLES

Figure 5 shows the photocatalytic activities of the $\mathrm{Fe}_{2} \mathrm{O}_{3}$ and $\mathrm{Fe}_{2} \mathrm{O}_{3}-\mathrm{CN}(x)$ samples for degradation of phenol under the exposure of $\mathrm{UV}$ or visible light irradiation for 25 h. $\mathrm{Fe}_{2} \mathrm{O}_{3}$ only showed $30 \%$ of phenol degradation under UV light irradiation. The addition of cyanamide clearly improved the photocatalytic activity of $\mathrm{Fe}_{2} \mathrm{O}_{3}$. When the mol ratio of added cyanamide was in the range of 2 to 6 , the activity increased from 49 to $75 \%$. Unfortunately, a further increase in cyanamide mol ratio did not further 
improve the photocatalytic activity. The activity was significantly dropped to $1 \%$ when the mol ratio of added cyanamide was 10 .

When the reaction was carried out under visible light irradiation, $\mathrm{Fe}_{2} \mathrm{O}_{3}$ did not show any photocatalytic activity. In contrast, all the $\mathrm{Fe}_{2} \mathrm{O}_{3}-\mathrm{CN}(x)$ samples showed photocatalytic activity under visible light irradiation. Similar to the reactions carried out under UV light irradiation, the activity increased from 40 to $80 \%$ when the mol ratio of cyanamide increased from 2 to 6 . Addition of a larger amount of cyanamide decreased the activity to $23 \%$. This result suggested that there was an optimum amount of cyanamide, which resulted in the optimum photocatalytic performance. This was obtained on the best sample, i.e., the $\mathrm{Fe}_{2} \mathrm{O}_{3}-\mathrm{CN}(6)$, both under $\mathrm{UV}$ and visible irradiation. The enhanced activity on the $\mathrm{Fe}_{2} \mathrm{O}_{3}-\mathrm{CN}(6)$ under UV and visible light irradiation would be caused by the decrease in the electron-hole recombination on the $\mathrm{Fe}_{2} \mathrm{O}_{3}$ as supported by the fluorescence emission spectra discussed above. In addition to the reduced electron-hole recombination, the better capability of the $\mathrm{Fe}_{2} \mathrm{O}_{3}-\mathrm{CN}(x)$ samples to absorb visible light than the $\mathrm{Fe}_{2} \mathrm{O}_{3}$ would also be an important parameter to give the high activity under visible light irradiation.

In order to investigate the activity of the $\mathrm{Fe}_{2} \mathrm{O}_{3}$ and the $\mathrm{Fe}_{2} \mathrm{O}_{3}-\mathrm{CN}(x)$ samples for photocatalytic degradation of phenol in the presence of other pollutants, urea was added in the system. As shown in the experimental results (Figure S1(A) in the Supplementary Information), degradation of phenol under UV light irradiation decreased when urea was present in the ratio 1:1 to phenol, in which the activity was further decreased when the ratio of urea was high (1:300). The photocatalytic activities for $\mathrm{Fe}_{2} \mathrm{O}_{3}$, $\mathrm{Fe}_{2} \mathrm{O}_{3}-\mathrm{CN}(2), \mathrm{Fe}_{2} \mathrm{O}_{3}-\mathrm{CN}(4)$ and $\mathrm{Fe}_{2} \mathrm{O}_{3}-\mathrm{CN}(6)$ followed the same trend as when they were used for photocatalytic degradation of phenol alone. However, it was clear that no activity could be recorded on the $\mathrm{Fe}_{2} \mathrm{O}_{3}-\mathrm{CN}(8)$ and the $\mathrm{Fe}_{2} \mathrm{O}_{3}-\mathrm{CN}(10)$ samples when urea was introduced into the system.

The photocatalytic reaction results carried out under the visible light are shown in Figure S1(B) in the Supplementary Information. No degradation of phenol was observed in the presence of urea on the $\mathrm{Fe}_{2} \mathrm{O}_{3}$ since originally it did not show any activity for phenol degradation under visible light irradiation. Similar to the results performed under UV light, the percentage degradation of phenol on the $\mathrm{Fe}_{2} \mathrm{O}_{3}-\mathrm{CN}(x)$ samples was slightly decreased when urea was added. The higher ratio of urea (1:300) lowered the photocatalytic degradation of phenol. The decreased photocatalytic degradation of phenol in the presence of urea under UV and visible light irradiation would be mostly caused by the competitive adsorption between phenol and urea on the photocatalyst. The adsorption of phenol on the photocatalyst after $2 \mathrm{~h}$ was slightly decreased from 13.5 to $12.9 \%$ in the presence of urea, and thus, led to a slight decrease in the photocatalytic degradation of phenol.

Besides urea, the effect of formaldehyde on the degradation of phenol was also investigated. As depicted in Figure S2(A) in the Supplementary Information, the percentage degradation of phenol under UV light exposure was affected by formaldehyde. Different from the case of urea that decreased the phenol degradation, there was no clear trend on the effect of formaldehyde. Some samples showed the positive effect of formaldehyde in improving the phenol removal, but some samples showed a negative effect. The improved percentage of phenol removal on some $\mathrm{Fe}_{2} \mathrm{O}_{3}-\mathrm{CN}(x)$ samples might come from the fact that phenol could react with formaldehyde to form a phenolic resin (Astarloa-Alerbe et al. 1998). On the other hand, the decrease in phenol degradation could be caused by competitive adsorption and oxidation between phenol and formaldehyde. The presence of formaldehyde resulted in the lower adsorption of phenol from 13.5 to $10.4 \%$ and the formaldehyde itself can be oxidized to form formic acid (Yang et al. 2000), which might inhibit the adsorption as well as the oxidation of phenol on the photocatalyst. All these parameters affected the phenol degradation on the $\mathrm{Fe}_{2} \mathrm{O}_{3}-\mathrm{CN}(x)$ samples.

Figure S2(B) in the Supplementary Information shows the percentage degradation of phenol in the presence of formaldehyde under visible light exposure. The results are obvious; the percentage degradation of phenol decreased in the presence of formaldehyde on all $\mathrm{Fe}_{2} \mathrm{O}_{3}-\mathrm{CN}(x)$ samples. It seems that phenolic resin could not be formed under visible light irradiation. The higher amount of the formaldehyde resulted in the lower amount of phenol percentage degradation. The low degradation of phenol would be caused by both competitive adsorption and oxidation between phenol and formaldehyde. Since the competitive adsorption between phenol and formaldehyde is higher than that of phenol and urea, the photocatalytic degradation of phenol in the presence of formaldehyde was more significantly decreased as compared to that carried out in the presence of urea. Furthermore, oxidation of formaldehyde might also occur and affected the oxidation of phenol. However, it was clear that the $\mathrm{Fe}_{2} \mathrm{O}_{3}-\mathrm{CN}(6)$ still showed the best photocatalytic activity towards degradation of phenol, either in the presence of formaldehyde or urea.

The photocatalytic degradation of phenol was also carried out in the presence of both urea and formaldehyde. 
Figure 6(a) shows the photocatalytic results when using UV light as the light source. When the ratio of phenol, urea, and formaldehyde was low $(1: 1: 1)$, the percentage degradation of phenol decreased in the presence of urea and formaldehyde, which would be mainly due to the competitive adsorption on the photocatalysts. The phenol adsorption decreased from 13.5 to $9 \%$ when both urea and formaldehyde were added into the system. In contrast, the percentage of phenol degradation increased when the ratio of urea and formaldehyde was high (1:300:300). There was a formation of white solid after the reactions only when such a high concentration of urea and formaldehyde was used. The white solid was confirmed by infrared spectroscopy to have the characteristics of the phenolic resin. This result is in good agreement with the previous report that phenol, urea, and formaldehyde can be also polymerized to form the phenolic resins $(\mathrm{Hu}$ et al. 2014). Another study also showed that phenol was consumed to form the phenolic resins, depending on the concentration of other feedstocks such as formaldehyde and urea (Astarloa-Alerbe et al. 1998). Therefore, the slight increase in the percentage of phenol removal would mainly come from the formation of the phenolic resins.

The percentage degradation of phenol under visible light irradiation in the presence of different ratios of phenol to urea to formaldehyde (1:1:1 and 1:300:300) is shown in Figure 6(b). Similar to the reactions under UV light irradiation, the percentage of phenol degradation decreased in the presence of urea and formaldehyde with a low ratio $(1: 1: 1)$. When the urea and formaldehyde were present at a higher concentration (1:300:300), the percentage degradation of phenol tended to increase and the phenolic resin was also formed after reactions under visible light irradiation. Considerable research can be carried out in order to determine the mechanism of photocatalytic degradation on phenol in the presence of urea and formaldehyde.

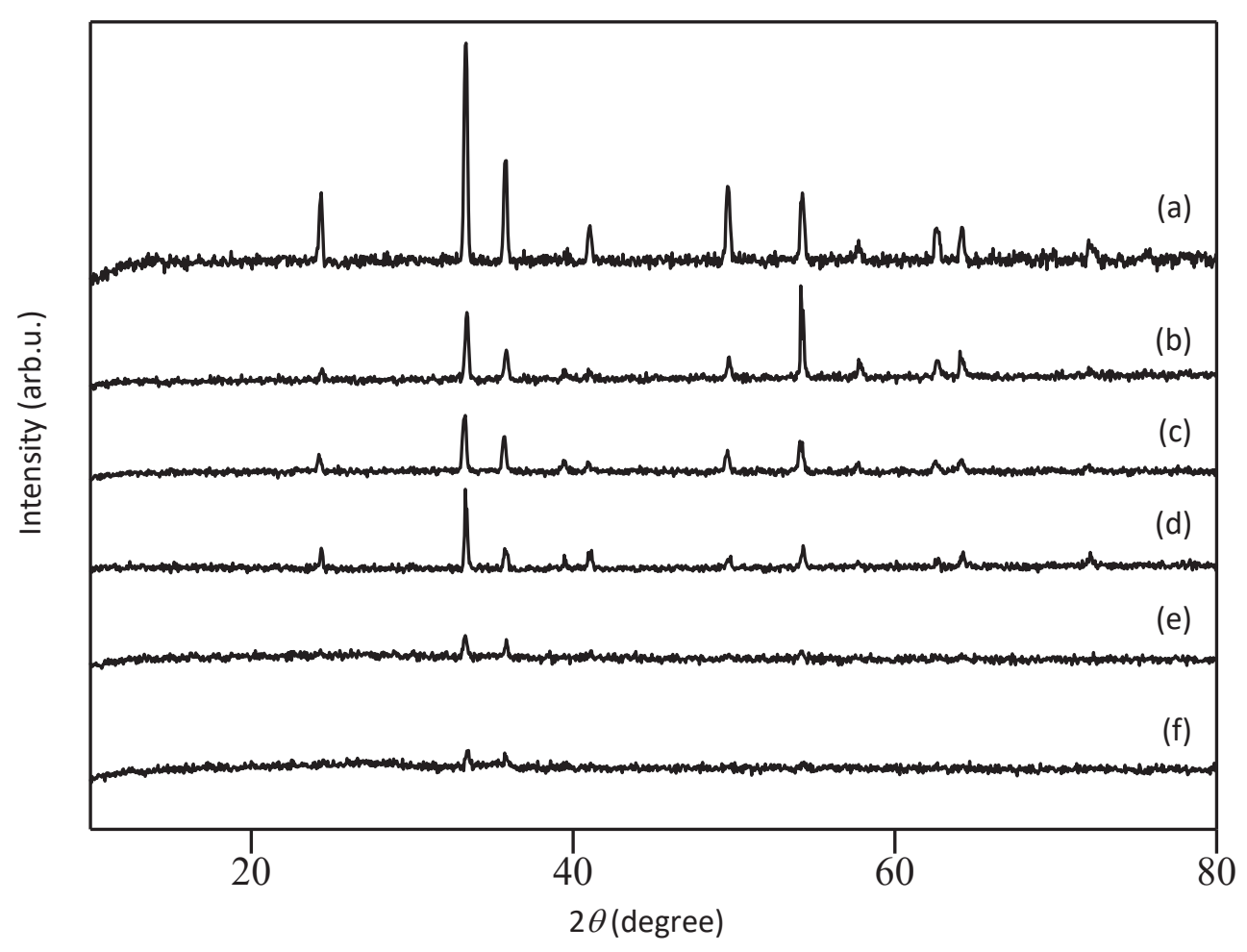

FIGURE 1. XRD patterns of (a) $\mathrm{Fe}_{2} \mathrm{O}_{3}$, (b) $\mathrm{Fe}_{2} \mathrm{O}_{3}-\mathrm{CN}(2)$, (c) $\mathrm{Fe}_{2} \mathrm{O}_{3}-\mathrm{CN}(4)$, (d) $\mathrm{Fe}_{2} \mathrm{O}_{3}-\mathrm{CN}(6)$, (e) $\mathrm{Fe}_{2} \mathrm{O}_{3}-\mathrm{CN}(8)$, and (f) $\mathrm{Fe}_{2} \mathrm{O}_{3}-\mathrm{CN}(10)$. Experimental conditions:

The crystal structure of the samples were characterized by X-ray diffraction (XRD) on Bruker AXS Diffrac plus release 2000 at room temperature and using $\mathrm{Cu}-\mathrm{K} \alpha$ radiation $(\lambda=1.5406 \AA)$ at $40 \mathrm{kV}$ and $40 \mathrm{~mA}$ 


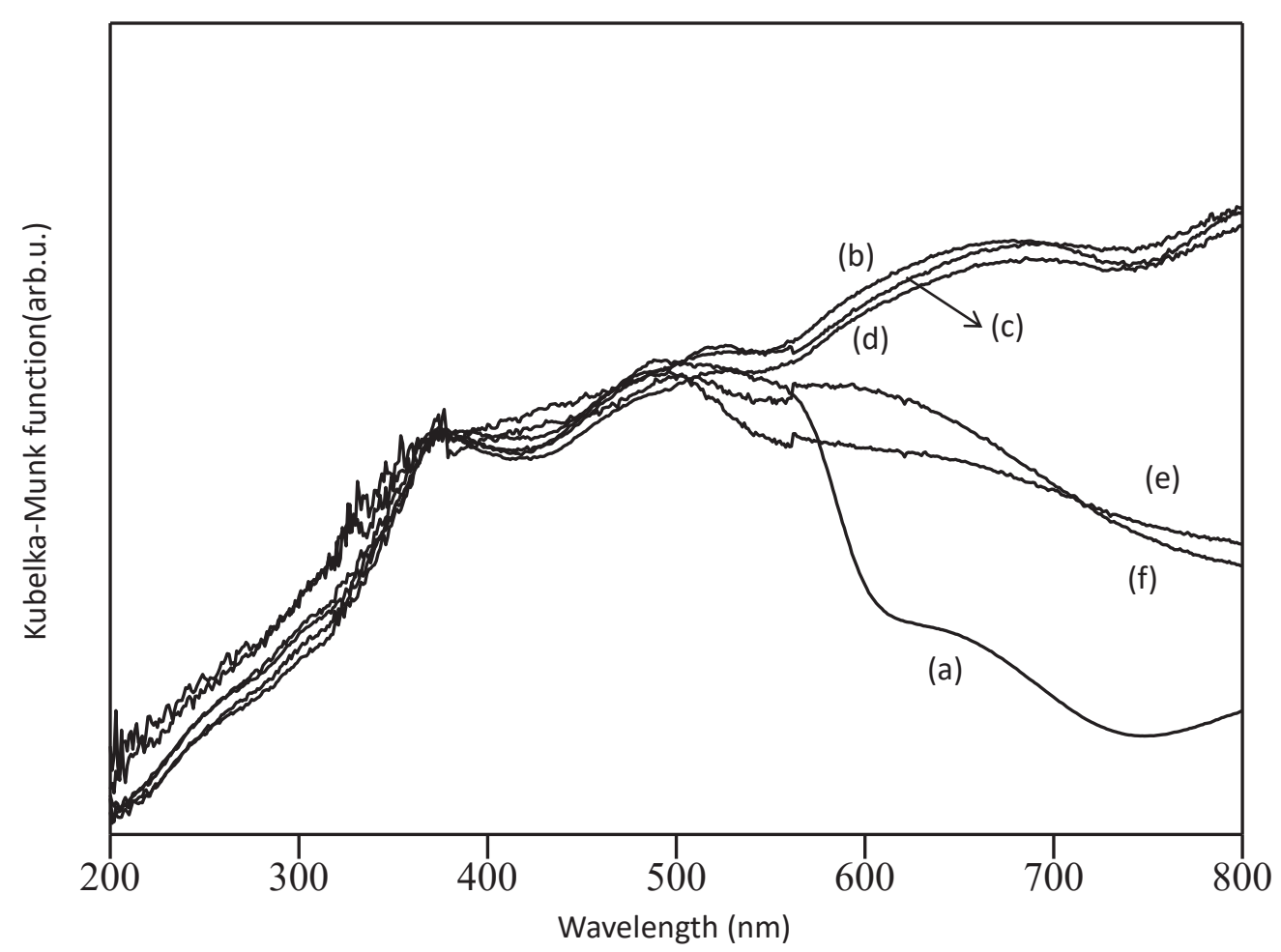

FIGURE 2. DR UV-Vis spectra of (a) $\mathrm{Fe}_{2} \mathrm{O}_{3}$, (b) $\mathrm{Fe}_{2} \mathrm{O}_{3}-\mathrm{CN}(2)$, (c) $\mathrm{Fe}_{2} \mathrm{O}_{3}-\mathrm{CN}(4)$, (d) $\mathrm{Fe}_{2} \mathrm{O}_{3}$ $\mathrm{CN}(6)$, (e) $\mathrm{Fe}_{2} \mathrm{O}_{3}-\mathrm{CN}(8)$, and (f) $\mathrm{Fe}_{2} \mathrm{O}_{3}-\mathrm{CN}(10)$. Experimental conditions: UV-visible diffuse reflectance (DR UV-vis) measurements using a Perkin Elmer Lambda 900 spectroscopy. The analysis range $200-800 \mathrm{~nm}$

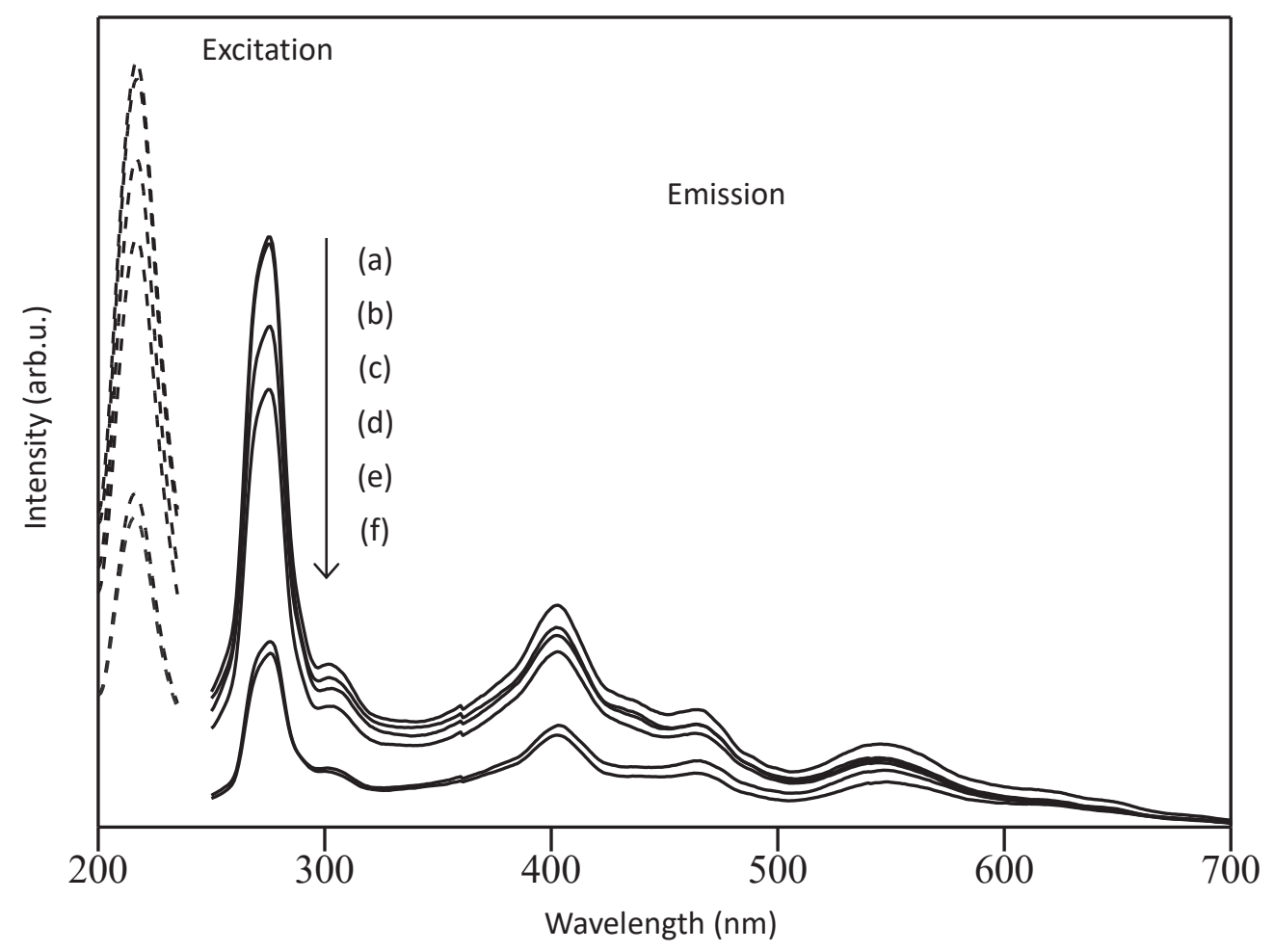

FIGURE 3. Excitation and emission spectra of (a) $\mathrm{Fe}_{2} \mathrm{O}_{3}$, (b) $\mathrm{Fe}_{2} \mathrm{O}_{3}-\mathrm{CN}\left(2\right.$ ), (c) $\mathrm{Fe}_{2} \mathrm{O}_{3}-\mathrm{CN}(4)$, (d) $\mathrm{Fe}_{2} \mathrm{O}_{3}$ $\mathrm{CN}(6)$, (e) $\mathrm{Fe}_{2} \mathrm{O}_{3}-\mathrm{CN}(8)$, and (f) $\mathrm{Fe}_{2} \mathrm{O}_{3}-\mathrm{CN}(10)$ samples. The monitoring wavelengths for excitation (broken line) and emission spectra (full line) were $276 \mathrm{~nm}$ and $217 \mathrm{~nm}$, respectively. Experimental conditions: the monitoring wavelengths for excitation and emission spectra were 217 and $276 \mathrm{~nm}$, respectively measured using JASCO Spectrofluorometer FP-8500 

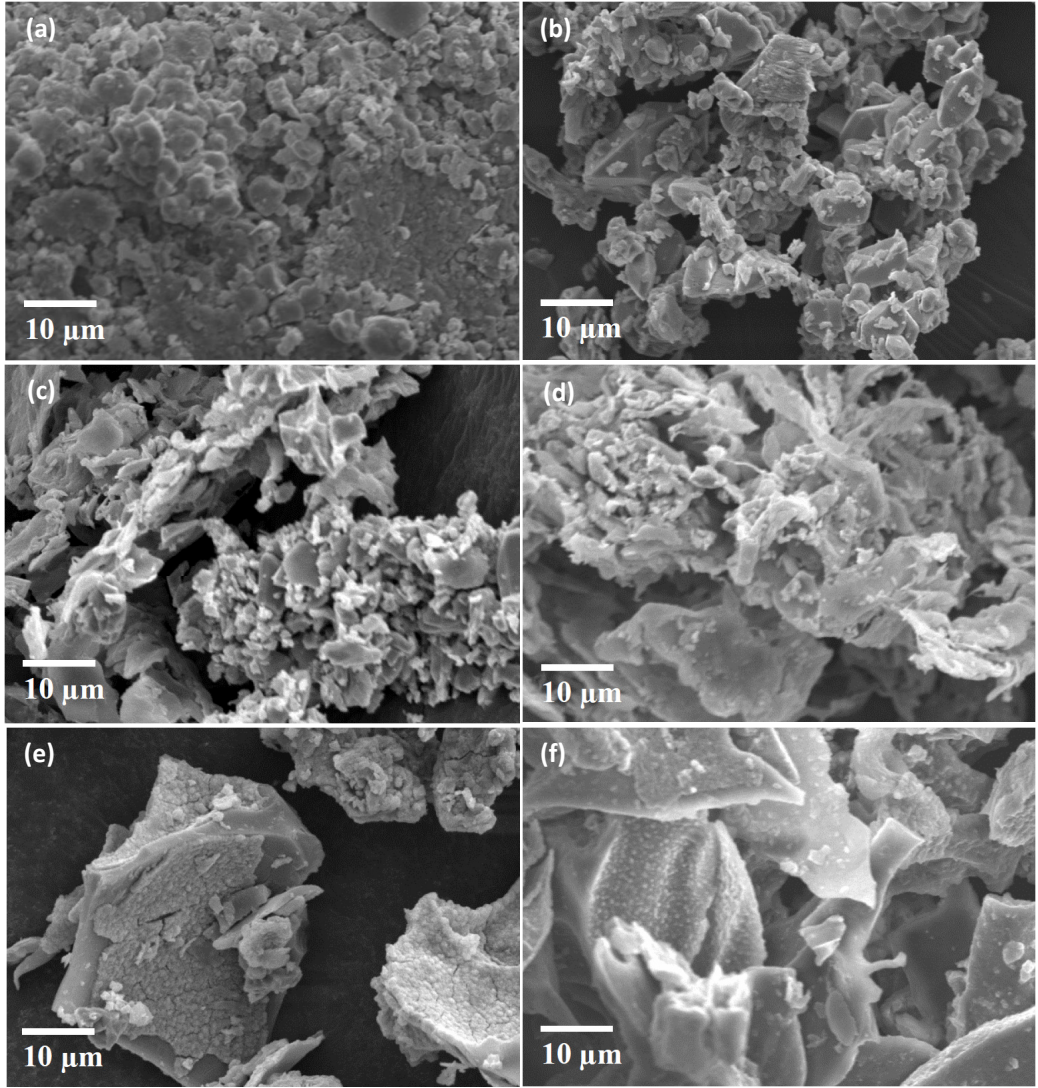

FIGURE 4. SEM images of (a) $\mathrm{Fe}_{2} \mathrm{O}_{3}$, (b) $\mathrm{Fe}_{2} \mathrm{O}_{3}-\mathrm{CN}(2)$, (c) $\mathrm{Fe}_{2} \mathrm{O}_{3}-\mathrm{CN}(4)$, (d) $\mathrm{Fe}_{2} \mathrm{O}_{3}-\mathrm{CN}(6)$, (e) $\mathrm{Fe}_{2} \mathrm{O}_{3}-\mathrm{CN}(8)$, and (f) $\mathrm{Fe}_{2} \mathrm{O}_{3}-\mathrm{CN}(10)$. Experimental conditions: the morphologies of the samples were characterized with scanning electron microscopy

(JEOL JSM-6390LV) with an accelerating voltage of $15 \mathrm{kV}$

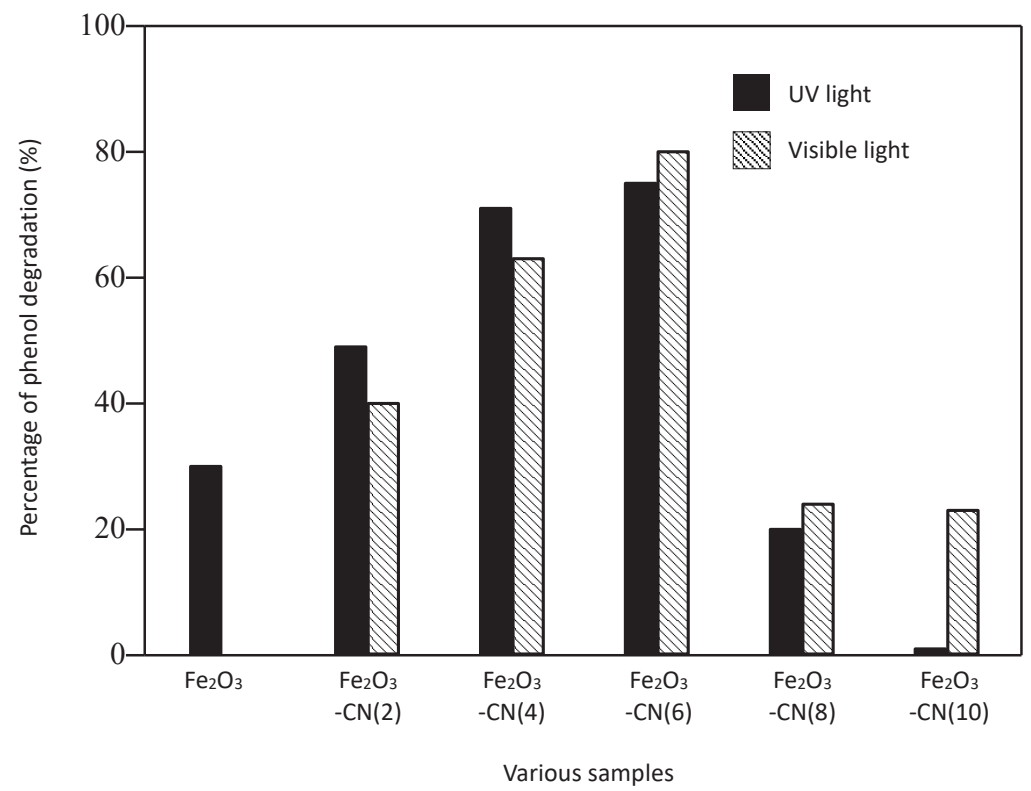

FIGURE 5. Phenol degradation on $\mathrm{Fe}_{2} \mathrm{O}_{3}$ and $\mathrm{Fe}_{2} \mathrm{O}_{3}-\mathrm{CN}(\mathrm{x})$ samples under $\mathrm{UV}$ and visible light irradiation. Experimental conditions: the photocatalytic activities were evaluated by phenol degradation under UV and visible light radiation. UV lamp used was a UVLS-28 EL series that emits UV light centered at 254 $\mathrm{nm}\left(8 \mathrm{~W}\right.$, intensity $\left.=0.8 \mathrm{~mW} / \mathrm{cm}^{2}\right)$. The visible lamp that was used was a halogen fiber optic illuminator MI-157 $(150 \mathrm{~W}$, intensity $=70000 \mathrm{~lx})$. In each experiment, $250 \mathrm{mg}$ of photocatalyst was added into $50 \mathrm{~mL}$ of phenol solution $(50 \mathrm{ppm})$. Before the reaction, the suspension was stirred for 2 hours in dark condition to reach adsorption-desoprtion equilibrium. After the suspension was exposed to the UV and visible light irradiation for $25 \mathrm{~h}$, the photocatalyst was filtrated from the solution 

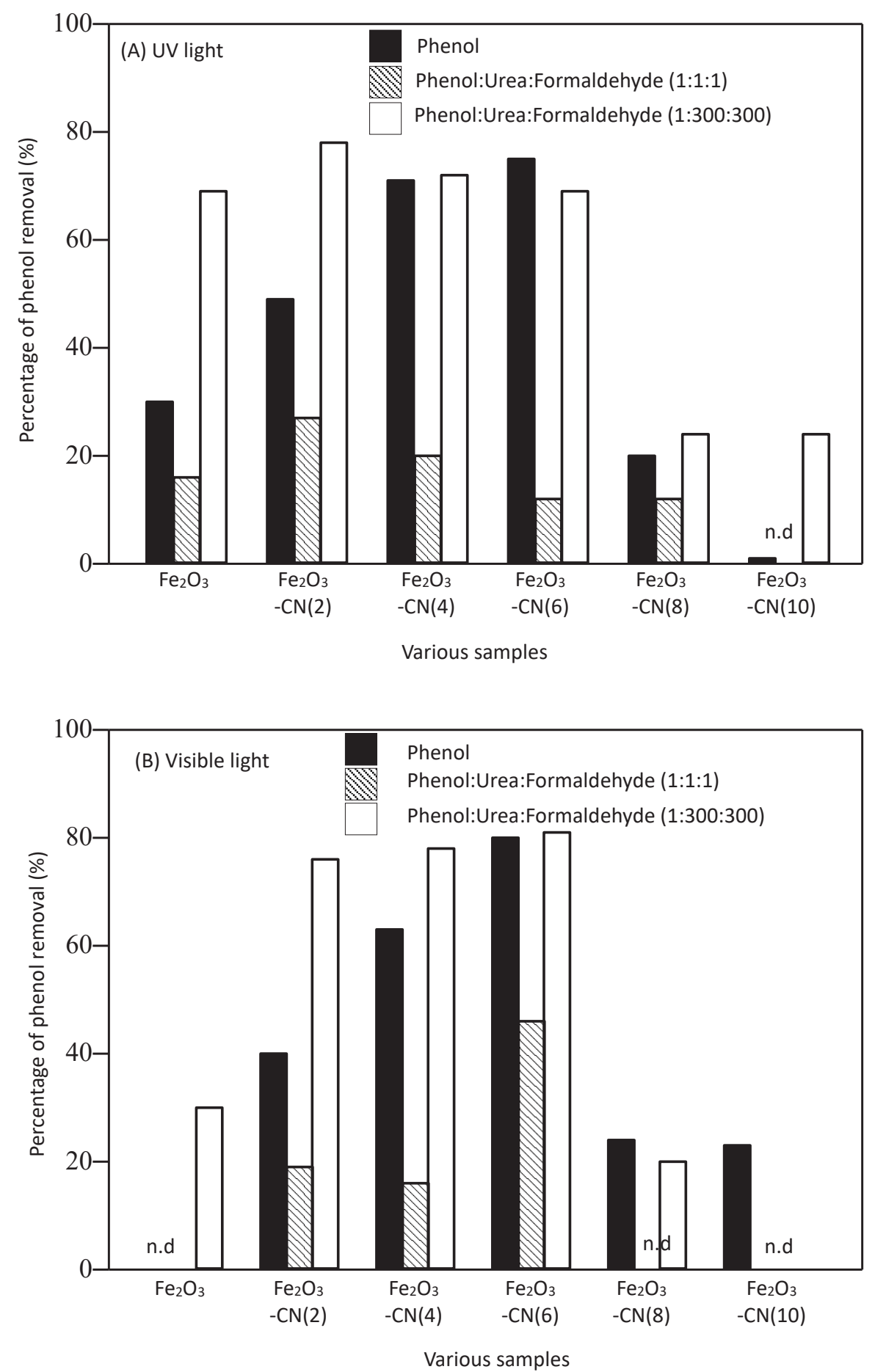

FIGURE 6. Phenol removal on $\mathrm{Fe}_{2} \mathrm{O}_{3}$ and $\mathrm{Fe}_{2} \mathrm{O}_{3}-\mathrm{CN}(\mathrm{x})$ samples under (A) UV light irradiation and (B) visible light irradiation in the presence of urea and formaldehyde. Experimental conditions: the photocatalytic activities were evaluated by phenol degradation under UV and visible light radiation. UV lamp used was a UVLS-28 EL series that emits UV light centered at $254 \mathrm{~nm}\left(8 \mathrm{~W}\right.$, intensity $\left.=0.8 \mathrm{~mW} / \mathrm{cm}^{2}\right)$. The visible lamp that was used was a halogen fiber optic illuminator MI-157 $(150 \mathrm{~W}$, intensity $=70000 \mathrm{~lx})$. In each experiment, $250 \mathrm{mg}$ of photocatalyst was added into $50 \mathrm{~mL}$ of phenol solution $(50 \mathrm{ppm})$. The concentration of urea or formaldehyde was fixed to be the same to phenol concentration or in excess, which gave phenol-ureaformaldehyde solutions (1:1:1 and 1:300:300). Before the reaction, the suspension was stirred for $2 \mathrm{~h}$ in dark condition to reach adsorption-desoprtion equilibrium. After the suspension was exposed to the UV and visible light irradiation for $25 \mathrm{~h}$, the photocatalyst was filtrated from the solution 


\section{CONCLUSION}

Cyanamide could be used as a modifier to improve the properties and photocatalytic activity of $\mathrm{Fe}_{2} \mathrm{O}_{3}$ photocatalyst. In general, the addition of cyanamide improved the absorption of $\mathrm{Fe}_{2} \mathrm{O}_{3}$ at visible light region and reduced the electron-hole recombination, resulting in the enhanced photocatalytic activity for degradation of phenol under UV or visible light irradiation. The best photocatalyst, the $\mathrm{Fe}_{2} \mathrm{O}_{3}-\mathrm{CN}(6)$, showed 75 and $80 \%$ of phenol degradation under UV and visible light, respectively, while the $\mathrm{Fe}_{2} \mathrm{O}_{3}$ only showed 30\% degradation under UV light and did not show any activity under visible light. The presence of urea slightly decreased the degradation of phenol due to the competitive adsorption. As for formaldehyde, the competitive adsorption and oxidation of formaldehyde could decrease the percentage removal of phenol. Since formaldehyde also could form phenolic resins with phenol, the percentage removal of phenol increased with the presence of formaldehyde. When both urea and formaldehyde are present in high concentration, photocatalytic removal of phenol was found to increase due to the formation of phenolic resin both under UV and visible light irradiation. This work demonstrated that the prepared cyanamide-modified $\mathrm{Fe}_{2} \mathrm{O}_{3}$ photocatalysts still could degrade phenol even though in the presence of other organic pollutants.

\section{ACKNOWLEDGEMENTS}

This work was financially supported by the Ministry of Higher Education (MOHE) and Universiti Teknologi Malaysia (UTM, Malaysia) through the Fundamental Research Grant Scheme (FRGS, cost center code: R.J130000.7826.4F002) and Research University Grant (RUG, Tier-2, cost center code: Q.J130000.2609.10J40) awarded to LY.

\section{REFERENCES}

Abdullah, A.M., Al-Thani, N.J., Tawbi, K. \& Al-Kandari, H. 2016. Carbon/nitrogen-doped $\mathrm{TiO}_{2}$ : New synthesis route, characterization and application for phenol degradation. Arabian Journal of Chemistry 9(2): 229-237.

Astarloa-Alerbe, G., Echeverria, J.M., Egiburu, J.L., Ormaetxea, M. \& Mondragon, I. 1998. Kinetics of phenolic resol resin formation by HPLC. Polymer 39(14): 3147-3153.

Bassi, P.S., Xianglin, L., Fang, Y., Loo, J.S.C., Barber, J. \& Wong, L.H. 2016. Understanding charge transport in non-doped pristine and surface passivated hematite $\left(\mathrm{Fe}_{2} \mathrm{O}_{3}\right)$ nanorods under front and backside illumination in the context of light induced water splitting. Physical Chemistry Chemical Physics 18(44): 30370-30378.
Buha, J., Djerdj, I., Antonietti, M. \& Niederberger, M. 2007. Thermal transformation of metal oxide nanoparticles into nanocrystalline metal nitrides using cyanamide and urea as nitrogen source. Chemistry of Materials 19(14): 34993505.

Cao, S., Fang, J., Shahjamali, M.M., Wang, Z., Yin, Z., Yang, Y., Boey, F.Y.C., Barber, J., Loo, S.Y.J. \& Xue, C. 2012. In situ growth of $\mathrm{Au}$ nanoparticles on $\mathrm{Fe}_{2} \mathrm{O}_{3}$ nanocrystals for catalytic applications. CrystEngComm 14(21): 7229-7235.

Cao, S. \& Zhu, Y. 2011. Monodisperse $\alpha-\mathrm{Fe}_{2} \mathrm{O}_{3}$ mesoporous microspheres: One-step NaCl-assisted microwavesolvothermal preparation, size control and photocatalytic property. Nanoscale Research Letter 6(1): 1.

Chemelewski, W.D., Mabayoje, O., Tang, D., Rettie, A.J.E. \& Mullins, C.B. 2016. Bandgap engineering of $\mathrm{Fe}_{2} \mathrm{O}_{3}$ with $\mathrm{Cr}$ - application to photoelectrochemical oxidation. Physical Chemistry Chemical Physics 18(3): 1644-1648.

Chen, L., Li, F., Ni, B., Xu, J., Fu, Z. \& Lu, Y. 2012. Enhanced visible photocatalytic activity of hybrid $\mathrm{Pt} / \alpha-\mathrm{Fe}_{2} \mathrm{O}_{3}$ nanorods. RSC Advances 2(26): 10057-10063.

Cheng, L., Qiu, S., Chen, J., Shao, J. \& Cao, S. 2017. A practical pathway for the preparation of $\mathrm{Fe}_{2} \mathrm{O}_{3}$ decorated $\mathrm{TiO}_{2}$ photocatalyst with enhanced visible-light photoactivity. Materials Chemistry and Physics 190: 53-61.

Cornell, R.M. \& Schwertmann, U. 2003. The Iron Oxides: Structure, Properties, Reactions, Occurrences and Uses. New Jersey: Wiley. pp. 701-705.

Dolat, D., Quici, N., Kusiak-Nejman, E., Morawski, A.W. \& Puma, G.L. 2012. One-step, hydrothermal synthesis of nitrogen, carbon co-doped titanium dioxide $\left(\mathrm{N}, \mathrm{CTiO}_{2}\right)$ photocatalysts. Effect of alcohol degree and chain length as carbon dopant precursors on photocatalytic activity and catalyst deactivation. Applied Catalysis B: Environmental 115-116: 81-89.

Guo, S., Zhang, G., Guo, Y. \& Yu, J.C. 2013. Graphene oxide$\mathrm{Fe}_{2} \mathrm{O}_{3}$ hybrid material as highly efficient heterogeneous catalyst for degradation of organic contaminants. Carbon 60: 437-444.

Hou, Y., Zuo, F., Dagg, A. \& Feng, P. 2013. A three - dimensional branched cobalt - doped $\alpha-\mathrm{Fe}_{2} \mathrm{O}_{3}$ nanorod $/ \mathrm{MgFe}_{2} \mathrm{O}_{4}$ heterojunction array as a flexible photoanode for efficient photoelectrochemical water oxidation. Angewandte Chemie International Edition 52(4): 1248-1252.

Hu, X., Zhao, Y., Cheng, W., Wang, D. \& Nie, W. 2014. Synthesis and characterization of phenol-urea-formaldehyde foaming resin used to block air leakage in mining. Polymer Composites 35(10): 2056-2066.

Karunakaran, C. \& Senthilvelan, S. 2006. $\mathrm{Fe}_{2} \mathrm{O}_{3}$-photocatalysis with sunlight and UV light: Oxidation of aniline. Electrochemistry Communications 8(1): 95-101.

Lee, S.C., Lintang, H.O. \& Yuliati, L. 2017. High photocatalytic activity of $\mathrm{Fe}_{2} \mathrm{O}_{3} / \mathrm{TiO}_{2}$ nanocomposites prepared by photodeposition for degradation of 2, 4-dichlorophenoxyacetic acid. Beilstein Journal of Nanotechnology 8: 915.

Li, H., Zhao, Q., Li, X., Zhu, Z., Tade, M. \& Liu, S. 2013. Fabrication, characterization, and photocatalytic property of 
$\alpha-\mathrm{Fe}_{2} \mathrm{O}_{3}$ /graphene oxide composite. Journal of Nanoparticle Research 15(6): 1670.

Li, P.G., Lei, M. \& Tang, W.H. 2008. Route to transition metal carbide nanoparticles through cyanamide and metal oxides. Materials Research Bulletin 43(12): 3621-3626.

Li, X., Yu, X., He, J. \& Xu, Z. 2009. Controllable fabrication, growth mechanisms, and photocatalytic properties of hematite hollow spindles. The Journal of Physical Chemistry C 113(7): 2837-2845.

Liang, P., Zhang, C., Sun, H., Liu, S., Tadé, M. \& Wang, S. 2016. Photocatalysis of $\mathrm{C}, \mathrm{N}$-doped $\mathrm{ZnO}$ derived from $\mathrm{ZIF}-8$ for dye degradation and water oxidation. RSC Advances 6(98): 95903-95909.

Lin, Y., Yuan, G., Sheehan, S., Zhou, S. \& Wang, D. 2011. Hematite-based solar water splitting: Challenges and opportunities. Energy \& Environmental Science 4(12): $4862-4869$.

Liu, G., Deng, Q., Wang, H., Dickon, H.L.N., Kong, M., Cai, W. \& Wang, G. 2012. Micro/nanostructured $\alpha-\mathrm{Fe}_{2} \mathrm{O}_{3}$ spheres: Synthesis, characterization, and structurally enhanced visiblelight photocatalytic activity. Journal of Materials Chemistry 22(19): 9704-9713.

Mirbagheri, N., Wang, D., Peng, C., Wang, J., Huang, Q., Fan, C. \& Ferapontova, E.E. 2014. Visible light driven photoelectrochemical water oxidation by $\mathrm{Zn}$-and Ti-doped hematite nanostructures. ACS Catalysis 4(6): 2006-2015.

Mohamed, M.A., Zain, M.F.M., Minggu, L.J., Kassim, M.B., Jaafar, J., Amin, N.A.S. \& Ng, Y.H. 2019. Revealing the role of kapok fibre as bio-template for in-situ construction of C-doped g- $\mathrm{C}_{3} \mathrm{~N}_{4} @ \mathrm{C}, \mathrm{N}$ co-doped $\mathrm{TiO}_{2}$ core-shell heterojunction photocatalyst and its photocatalytic hydrogen production performance. Applied Surface Science 476: 205-220.

Mohamed, M.A., Abdul Rahman, N., Zain, M.F.M., Minggu, L.J., Kassim, M.B., Jaafar, J., Samad, S., Mastuli, M.S. \& Wong, R.J. 2020. Hematite microcube decorated $\mathrm{TiO}_{2}$ nanorods as heterojunction photocatalyst with in-situ carbon doping derived from polysaccharides bio-templates hydrothermal carbonization. Journal of Alloys and Compounds 820: 153143.

Mohamed, M.A., Wan Salleh, W.N., Jaafar, J., Rosmi, M.S., Mohd. Hir, Z.A., Abd Mutalib, M., Ismail, A.M. \& Tanemura, M. 2017. Carbon as amorphous shell and interstitial dopant in mesoporous rutile $\mathrm{TiO}_{2}$ : bio-template assisted sol-gel synthesis and photocatalytic activity. Applied Surface Science 393: 46-59.

Mou, F., Xu, L., Ma, H., Guan, J., Chen, D. \& Wang, S. 2012. Facile preparation of magnetic $\gamma-\mathrm{Fe}_{2} \mathrm{O}_{3} / \mathrm{TiO}_{2}$ Janus hollow bowls with efficient visible-light photocatalytic activities by asymmetric shrinkage. Nanoscale 4(15): 4650-4657.

Pradhan, G.K., Sahu, N. \& Parida, K.M. 2013. Fabrication of $\mathrm{S}, \mathrm{N}$ co-doped $\alpha-\mathrm{Fe}_{2} \mathrm{O}_{3}$ nanostructures: Effect of doping, $\mathrm{OH}$ radical formation, surface area, [110] plane and particle size on the photocatalytic activity. RSC Advances 3(21): 7912-7920.

Qiu, Y., Leung, S., Zhang, Q., Hua, B., Lin, Q., Wei, Z., Tsui, K., Zhang, Y., Yang, S. \& Fan, Z. 2014. Efficient photoelectrochemical water splitting with ultrathin films of hematite on three-dimensional nanophotonic structures. Nano Letters 14(4): 2123-2129.

Roslan, N.A., Lintang, H.O. \& Yuliati, L. 2014. Preparation of iron (III) oxide nanoparticles using a mesoporous carbon nitride template for photocatalytic phenol removal. Materials Research Innovations 18(6): S6-465-S6-469.

Sivula, K., Le Formal, F. \& Grätzel, M. 2011. Solar water splitting: Progress using hematite $\left(\alpha-\mathrm{Fe}_{2} \mathrm{O}_{3}\right)$ photoelectrodes. ChemSusChem 4(4): 432-449.

Stroyuk, A.L., Sobran, I.V. \& Kuchmiy, S.Y. 2007. Photoinitiation of acrylamide polymerization by $\mathrm{Fe}_{2} \mathrm{O}_{3}$ nanoparticles. Journal of Photochemistry and Photobiology A: Chemistry 192(2): 98-104.

Sundaramurthy, J., Kumar, P.S., Kalaivani, M., Thavasi, V., Mhaisalkar, S.G. \& Ramakrishna, S. 2012. Superior photocatalytic behaviour of novel 1D nanobraid and nanoporous $\alpha-\mathrm{Fe}_{2} \mathrm{O}_{3}$ structures. RSC Advances 2(21): 82018208.

Thomas, A., Fischer, A., Goettmann, F., Antonietti, M., Müller, J., Schlögl, R. \& Carlsson, J.M. 2008. Graphitic carbon nitride materials: variation of structure and morphology and their use as metal-free catalysts. Journal of Materials Chemistry 18(41): 4893-4908.

Thomas, P., Sreekanth, P. \& Abraham, K.E. 2015. Nanosecond and ultrafast optical power limiting in luminescent $\mathrm{Fe}_{2} \mathrm{O}_{3}$ hexagonal nanomorphotype. Journal of Applied Physics 117(5): 053103.

Wang, X., Blechert, S. \& Antonietti, M. 2012. Polymeric graphitic carbon nitride for heterogeneous photocatalysis. ACS Catalysis 2(8): 1596-1606.

Wen, X.H. \& Pan, H.J. 2012. Electron properties of F, and N doped hematite: The application for photocatalysis. Advanced Materials Research 562-564: 298-301.

Xu, Y., Zhang, G., Du, G., Sun, Y. \& Gao, D. 2013. $\alpha-\mathrm{Fe}_{2} \mathrm{O}_{3}$ nanostructures with different morphologies: Additive-free synthesis, magnetic properties, and visible light photocatalytic properties. Materials Letters 92: 321-324.

Yang, J., Li, D., Zhang, Z., Li, Q. \& Wang, H. 2000. A study of the photocatalytic oxidation of formaldehyde on $\mathrm{Pt} / \mathrm{Fe}_{2} \mathrm{O}_{3} / \mathrm{TiO}_{2}$. Journal of Photochemistry and Photobiology A: Chemistry 137(2-3): 197-202.

Yang, S., Xu, Y., Sun, Y., Zhang, G. \& Gao, D. 2012. Sizecontrolled synthesis, magnetic property, and photocatalytic property of uniform $\alpha-\mathrm{Fe}_{2} \mathrm{O}_{3}$ nanoparticles via a facile additive-free hydrothermal route. CrystEngComm 14(23): 7915-7921.

Yu, B. \& Kwak, S. 2012. Carbon quantum dots embedded with mesoporous hematite nanospheres as efficient visible lightactive photocatalysts. Journal of Materials Chemistry 22(17): 8345-8353.

Yusoff, N., Ho, L., Ong, S. \& Wong, Y. 2017. Enhanced photodegradation of phenol by $\mathrm{ZnO}$ nanoparticles synthesized through sol-gel method. Sains Malaysiana 46(12): 25072514.

Zhang, H., Ming, H., Lian, S., Huang, H., Li, H., Zhang, L., Liu, Y., Kang, Z. \& Lee, S. 2011. $\mathrm{Fe}_{2} \mathrm{O}_{3}$ /carbon quantum dots 
complex photocatalysts and their enhanced photocatalytic activity under visible light. Dalton Transactions 40(41): 10822-10825.

Zhang, M., Luo, W., Li, Z., Yu, T. \& Zou, Z. 2010. Improved photoelectrochemical responses of $\mathrm{Si}$ and Ti codoped $\alpha-\mathrm{Fe}_{2} \mathrm{O}_{3}$ photoanode films. Applied Physics Letters 97(4): 042105.

Zhang, Y., Jiang, S., Song, W., Zhou, P., Ji, H., Ma, W., Hao, W., Chen, C. \& Zhao, J. 2015. Nonmetal P-doped hematite photoanode with enhanced electron mobility and high water oxidation activity. Energy \& Environmental Science 8(4): 1231-1236.

Zhao, W., Liu, Y., Liu, J., Chen, P., Chen, I.W., Huang, F. \& Lin, J. 2013. Controllable synthesis of silver cyanamide as a new semiconductor photocatalyst under visible-light irradiation. Journal of Materials Chemistry A 1(27): 7942-7948.

Nur Azmina Roslan*

Malaysian Palm Oil Board

No. 6, Persiaran Institusi, Bandar Baru Bangi

43000 Kajang, Selangor Darul Ehsan

Malaysia

Nur Azmina Roslan*

Department of Chemistry

Faculty of Science

Universiti Teknologi Malaysia

81310 UTM, Johor Bahru, Johor Darul Takzim

Malaysia
Hendrik O. Lintang \& Leny Yuliati

Ma Chung Research Center for Photosynthetic Pigments Universitas Ma Chung

Villa Puncak Tidar N-01

Malang 65151, East Java

Indonesia

Hendrik O. Lintang \& Leny Yuliati

Department of Chemistry

Faculty of Science and Technology

Universitas Ma Chung

Villa Puncak Tidar N-01

Malang 65151, East Java

Indonesia

Hendrik O. Lintang \& Leny Yuliati*

Centre for Sustainable Nanomaterials

Ibnu Sina Institute for Scientific and Industrial Research

Universiti Teknologi Malaysia

81310 UTM Johor Bahru, Johor Darul Takzim

Malaysia

*Corresponding author; email: nazmina@mpob.gov.my

Received: 7 January 2021

Accepted: 15 April 2021 


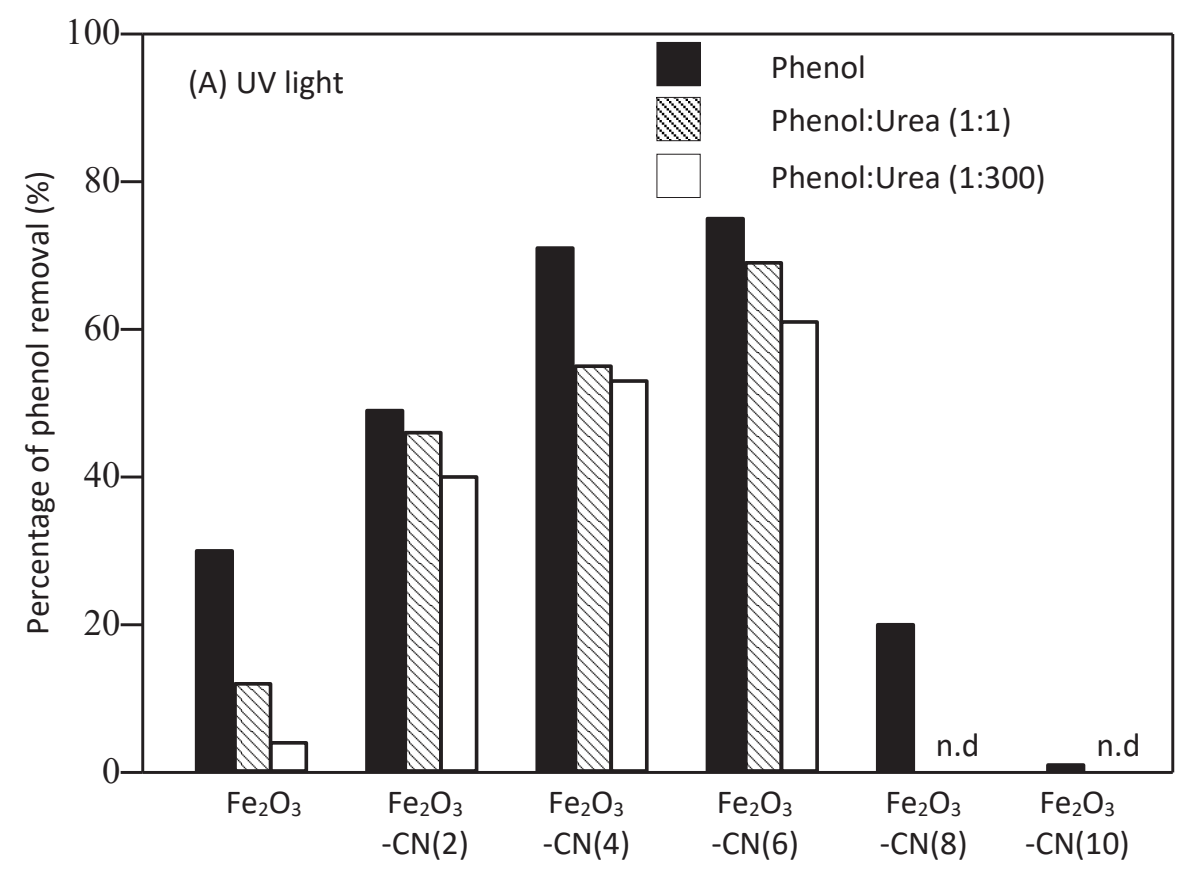

Various samples

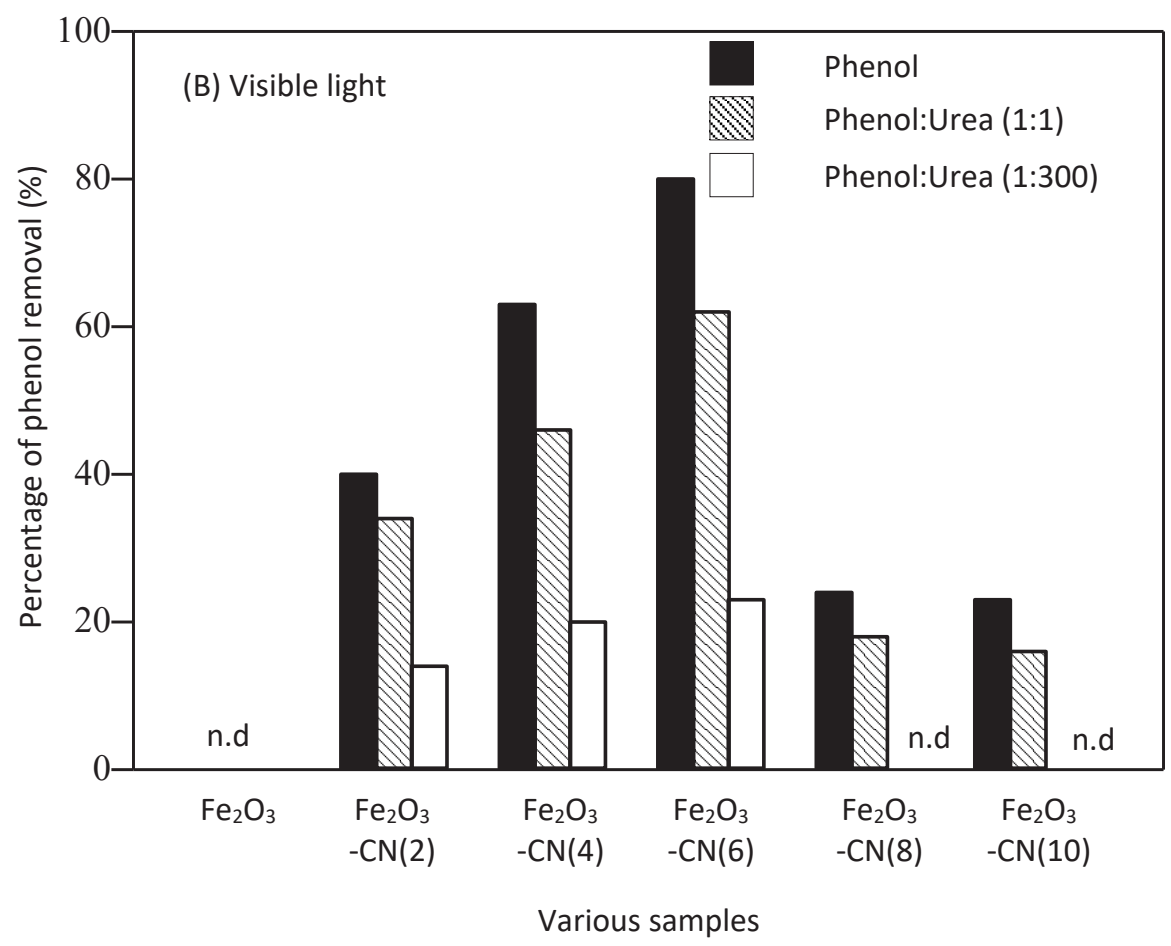

FIGURE. S1 Phenol removal on $\mathrm{Fe}_{2} \mathrm{O}_{3}$ and $\mathrm{Fe}_{2} \mathrm{O}_{3}-\mathrm{CN}(\mathrm{x})$ samples under (A) UV light irradiation and $(\mathrm{B})$ visible light irradiation in the presence of urea. Experimental conditions: the photocatalytic activities were evaluated by phenol degradation under UV and visible light radiation. UV lamp used was a UVLS-28 EL series that emits UV light centered at $254 \mathrm{~nm}\left(8 \mathrm{~W}\right.$, intensity $\left.=0.8 \mathrm{~mW} / \mathrm{cm}^{2}\right)$. The visible lamp that was used was a halogen fibre optic illuminator MI-157 $(150 \mathrm{~W}$, intensity $=70000 \mathrm{~lx})$. In each experiment, $250 \mathrm{mg}$ of photocatalyst was added into $50 \mathrm{~mL}$ of phenol solution (50 ppm). The concentration of urea or formaldehyde was fixed to be the same to phenol concentration or in excess, which gave phenol-urea (1:1 and 1:300). Before the reaction, the suspension was stirred for 2 hours in dark condition to reach adsorption-desorption equilibrium. After the suspension was exposed to the

UV and visible light irradiation for 25 hours, the photocatalyst was filtrated from the solution. 

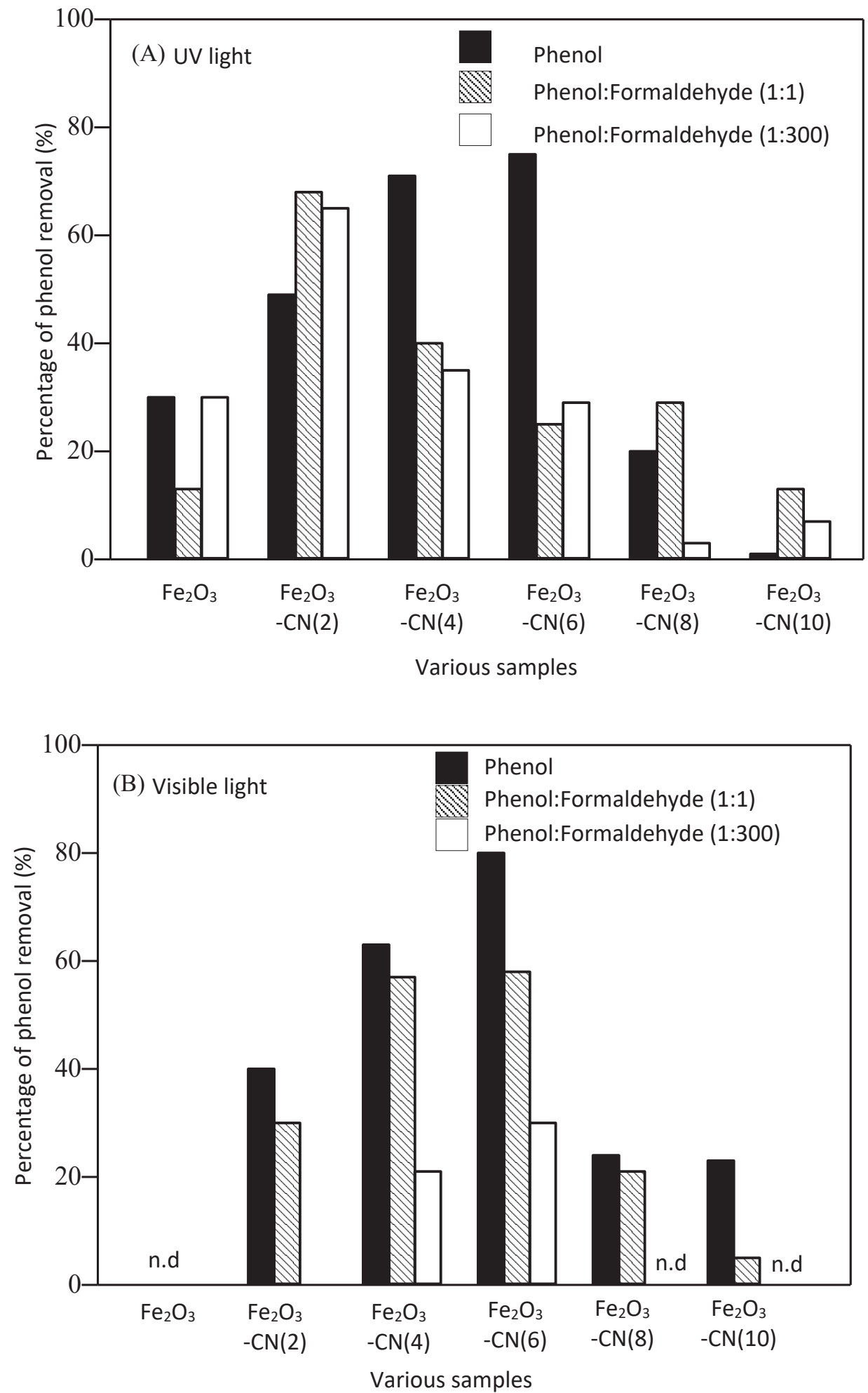

FIGURE. S2 Phenol removal on $\mathrm{Fe}_{2} \mathrm{O}_{3}$ and $\mathrm{Fe}_{2} \mathrm{O}_{3}-\mathrm{CN}(\mathrm{x})$ samples under (A) UV light irradiation and (B) visible light irradiation in the presence of formaldehyde. Experimental conditions: the photocatalytic activities were evaluated by phenol degradation under UV and visible light radiation. UV lamp used was a UVLS-28 EL series that emits UV light centered at $254 \mathrm{~nm}\left(8 \mathrm{~W}\right.$, intensity $\left.=0.8 \mathrm{~mW} / \mathrm{cm}^{2}\right)$. The visible lamp that was used was a halogen fibre optic illuminator MI-157 $(150 \mathrm{~W}$, intensity $=70000 \mathrm{~lx})$. In each experiment, $250 \mathrm{mg}$ of photocatalyst was added into $50 \mathrm{~mL}$ of phenol solution $(50 \mathrm{ppm})$. The concentration of urea or formaldehyde was fixed to be the same to phenol concentration or in excess, which gave phenol-formaldehyde (1:1 and 1:300). Before the reaction, the suspension was stirred for 2 hours in dark condition to reach adsorption-desorption equilibrium. After the suspension was exposed to the UV and visible light irradiation for 25 hours, the photocatalyst was filtrated from the solution. 